Aim of the study: The paper presents the results of examining the level of acceptance of the illness in cancer patients using the Acceptance of Illness Scale (AIS).

Material and methods: The study involved cancer patients treated at the Central Clinical Hospital of the Ministry the Interior in Warsaw in 2014. The questionnaire comprised basic demographic questions (socio-economic factors) and the AIS test estimating the level of illness acceptance in patients.

Results: For the group of patients in the research group, the arithmetic mean amounted to 27.56 points. The period of time that elapsed between the first cancer diagnosis and the start of the study did not influence the score of accepting illness. The acceptance of illness in patients diagnosed with metastases differed from the acceptance of illness by patients diagnosed with metastatic cancer. Females obtained the average of 29.59 in the AIS test, whereas the average in male patients was 26.17. The patients' age did not impact the AIS test. There were no differences in the AIS test results between a group of people with secondary education and a group of people with higher education. There were no differences in the AIS test results between employed individuals versus pensioners. The inhabitants of cities were characterized by the highest degree of acceptance of their health condition. The lowest degree of acceptance of illness was observed in the group with the lowest average incomes. In the group of married individuals the average degree of acceptance of illness amounted to 27.37 points. The average degree of acceptance of illness in patients that declared themselves as single amounted to 25.75 .

Conclusions: The average degree of acceptance of illness in the study group was 27.56 points, which is a relatively high level of acceptance of cancer. The main socio-economic factor, which influenced the AIS test results was whether metastases were diagnosed or not. There were no differences between patients in groups where the time that elapsed from the first diagnosis of cancer varied. There were no statistical differences between female and male patients as well as patients of different age. Additionally, the level of education and patients' professional status did not impact in the AIS test results.

Key words: quality of life, Acceptance of Illness Scale, AIS.

Contemp Oncol (Pozn) 2016; 20 (3): 261-265 DOI: $10.5114 /$ wo.2015.54901

\section{The assessment of the impact of socio-economic factors in accepting cancer using the Acceptance of Illness Scale (AIS)}

\author{
Aleksandra I. Czerw ${ }^{1}$, Magdalena Bilińska ${ }^{1}$, Andrzej Deptała ${ }^{2,3}$ \\ ${ }^{1}$ Department of Public Health, Medical University of Warsaw, Poland \\ ${ }^{2}$ Division of Cancer Prevention, Medical University of Warsaw, Poland \\ ${ }^{3}$ Department of Oncology and Haematology CSK MSW, Warsaw, Poland
}

\section{Introduction}

In 1994 the World Health Organization defined the quality of life as individuals' perception of their position in life in the context of the culture and value systems in which they live and in relation to their goals, expectations, standards and concerns. In order to measure the quality of life, several components should be determined. This gives the opportunity to look at the multidimensionality of the impact that an illness has on the patient [1].

The assessment of quality of life is not only used in clinical research, but also in diagnostics and measuring the outcomes of therapeutic and rehabilitation programmes. The assessment of quality of life is also used when making decisions regarding treatment or its optimization [2]. It should also be emphasized that the assessment of the patients' quality of life should not be carried out by means of questionnaires only, which we cannot treat as an overall research procedure. The optimal approach should also take into account the patient's personality and autonomy of the illness [3].

The ability to accept illness is a major issue in the quality of life of cancer patients. The assessment of acceptance of illness is conducted at two levels: emotional and cognitive-behavioural. Affecting numerous aspects of the patient's life, i.e. physical, mental, social and spiritual, is a natural effect of cancer. Patients learn to cope not only with the symptoms of the illness but also with the resulting changes in the quality of life, limitation of autonomy and independence, and the change of their individual roles in their families and society.

During the initial phase, i.e. from the moment of noticing the symptoms to the moment of diagnosis, the patient is faced with a new, unknown situation. The moment of informing the patient about the diagnosis is very important. The following factors aggravate the stress: cancer with poor prognosis, difficult living conditions, social situation, and young age of the patient. Patients sometimes experience emotional trauma. It is often accompanied by acute stress reactions: fear of losing control, problems with concentration, despair, a feeling of the unreality of the situation. The diagnosis and treatment can result in social isolation and thoughts about death. Patients often feel stigmatized. All this builds up and influences the way people adjust to and accept the illness [4].

The above mentioned issues can prove the important role of psycho-oncology in patient care. Psychological support given to the patient may accelerate the process of adaptation to the illness and improve the quality of life [5].

The pro-health policy and health education followed by public institutions and non-governmental organizations play an important role in the context of the quality of life of cancer patients $[6,7]$. The funds allocated for the National Programme for Combating Cancer in Poland in 2013 amounted to 
252.5 million PLN [8]. In France, the budget for the implementation of the National Programme for Combating Cancer for the period 2014-2019 amounts to 1.5 billion EUR [9]. In the United States, the operating budget of the National Cancer Institute in 2013 was 5.833 billion USD [9].

The objective of the study was to present the results of assessing the level of acceptance among cancer patients using the Acceptance of Illness Scale (AIS).

A hypothesis about the impact of socio-economic factors on the AIS test results was formulated. The level of acceptance of the illness was compared with patients' level of education, gender, marital status, place of residence, net income per family member and professional status.

\section{Material and methods}

The subject of the study was a group of 74 cancer patients treated at the Department of Oncology and Haematology at the Central Clinical Hospital of the Ministry of the Interior in Warsaw between February and April 2014. The research group comprised patients diagnosed with pancreatic and colorectal cancer: 29 women and 42 men, aged from 23 to 82.

The research tool was a questionnaire consisting of three parts: questions asked before the test (introductory questions), the Acceptance of Illness Scale (AIS) questionnaire and a part on demographics, which totalled to 20 multiple-choice questions and two open-ended questions (regarding the month and year when patients were diagnosed with cancer for the first time and their year of birth). The study was carried out by direct contact with the patient - using the PAPI (Paper and Pencil Interview) method. 71 correctly completed questionnaires were analysed.

The Acceptance of Illness Scale is one of the tools used to assess how the patient copes with the illness [10]. It examines the extent to which the patient is able to accept the illness without experiencing negative emotions or reactions. On this scale, there are eight statements relating to the negative consequences of ill health. These consequences are based on the recognition of the limitations imposed by the illness, a sense of dependence on others, a lowered self-esteem and a lack of self-sufficiency. The design of the scale allows the assessment of the degree of acceptance in patients with any disease entity. It is applicable only to adults who are

Table 1. Summary results of the AIS test

\begin{tabular}{|cccccc|}
\hline N & Minimum & Maximum & Average & $\begin{array}{c}\text { Standard } \\
\text { deviation }\end{array}$ & Median \\
\hline 71 & 9 & 40 & 27,56 & 8,522 & 28,00 \\
\hline
\end{tabular}

Table 2. Results of the AIS test and the time of diagnosis

$\begin{array}{lccc}\begin{array}{l}\text { When were you diagnosed with } \\ \text { cancer for the first time? }\end{array} & \boldsymbol{N} & \text { Average } & \begin{array}{c}\text { Standard } \\ \text { deviation }\end{array} \\ \begin{array}{l}\text { Less than a year ago } \\ \text { Two years ago }\end{array} & 37 & 29.49 & 7.63 \\ \text { More than two years ago } & 17 & 25.29 & 9.15 \\ \text { In total } & 71 & 27.56 & 8.52\end{array}$

currently suffering from any illness. It is acknowledged that the higher the acceptance level of the illness, the better the adaptation and the lower psychological discomfort. For each of the eight statements used in the AIS, a scale ranging from 1 to 5 is assigned. The examined individual selects one of the numbers corresponding to their current condition in the most appropriate way. Number 1, refers to the statement: "I strongly agree" and number 5 refers to: "I strongly disagree". Selecting number 1 on the scale expresses poor adaptation to the illness, while choosing number 5 means complete acceptance of the illness. The patient may obtain from 8 to 40 points, which correspond to the degree of acceptance of illness. A low score indicates lack of adaptation to illness and its acceptance accompanied by a strong psychological discomfort. On the contrary, the result close to 40 points indicates the acceptance of the illness which demonstrates hardly any negative emotions associated with the illness.

For the statistical analysis of the results, the following were used: reliability statistics (Cronbach's $\alpha$ ), Levene's homogeneity of variance test, Analysis of Variance (ANOVA) and Mann-Whitney $U$ test. The statistical analysis was performed using SPSS.

\section{Results}

The Cronbach's $\alpha$ coefficient for the studied sample group amounted to 0.871. In comparison, Cronbach's $\alpha$ coefficient for the internal consistency reliability of the AIS, carried out while adapting questionnaires to the Polish environment, amounted to 0.85 [4]. Therefore it points out that the test carried out for the purpose of the study was characterized by satisfactory reliability, and the obtained reliability was similar to universally achieved levels.

Table 1 presents the collective results obtained in the study. The lowest score was 9 points and indicated no adaptation nor acceptance of illness, and mental discomfort. The maximum score was 40, which indicated the acceptance of one's own illness and the absence of negative emotions associated with it. For the group of patients included in the study, the arithmetic mean amounted to 27.56 points, and the standard deviation amounted to 8.522.

The AIS test results from patients divided into three groups depending on the time that elapsed from the first diagnosis of cancer is presented in Table 2. The largest group of patients were those whose cancer was diagnosed approximately a year ago $(n=37)$. Both groups - of patients diagnosed with cancer two years ago, and those diagnosed with cancer over two years ago were equal $(n=17)$. The Analysis of Variance (ANOVA) was carried out. Its statistical significance proved to be higher than 0.05 (0.139). Thus, the hypothesis that the period of time that elapsed between the first cancer diagnosis and the start of the study did not influence the illness acceptance, was not rejected.

Table 3 presents the acceptance of illness when compared with the diagnosis of metastases or lack thereof. The Levene's homogeneity of variance tests were carried out for both groups of patients (those who were diagnosed with metastases and those who were not diagnosed with metastases). The patients who ticked the answer: 'I do not 
know' were not taken into account due to the very small size of this group $(n=1)$. The respondents with diagnosed metastases counted a group of 32 people, while respondents with no metastases diagnosed - 38 people. The statistical significance of the test exceeded 0.05 (amounting to 0.153 ). Therefore, a conclusion can be drawn that there was no basis for excluding the homogeneity of variance assumption. The Analysis of Variance (ANOVA) was carried out, in which the statistical significance of the variance did not exceed 0.05. Consequently, the hypothesis that there was no difference between the groups (patients with metastases versus patients without metastases) was rejected. The acceptance of the illness in patients diagnosed with metastases was different from the acceptance of the illness in patients diagnosed with metastatic cancer.

Table 4 presents the level of acceptance of the illness according to patients' gender. In the AIS test the female group obtained the average of 29.59, which is higher than the average in the male group (26.17). The statistical significance of the Levene's homogeneity of variance test exceeded 0.05 (amounting to 0.386). Therefore, there was no basis for rejecting the homogeneity of variance assumption. The statistical significance in the Analysis of Variance (ANOVA) amounted to 0.097. Again, there was no basis for rejecting the hypothesis that there is no difference in the AIS test results between the female and male groups, on the basis of the statistical significance of differences test.

Table 5 presents the results of the AIS test in different age groups. In patients under the age of $55(n=23)$, the average number of points obtained in the test was 28 . In patients aged 55-65 $(n=27)$ the average number of points obtained in the test was 27.74. In patients aged 65 and over, whose group was the least numerous, $(n=21)$ the average number of points obtained in the test was 26.86 . The statistical significance of the Levene's homogeneity of variance test was 0.85 . There was no basis for rejecting the homogeneity of variance assumption. In order to compare the results, the Analysis of Variance (ANOVA) was performed, giving the statistical significance at the level of 0.9. Thus, age did not make any difference between the results obtained under the AIS test.

The degree of acceptance of illness with respect to patients' level of education is presented in Table 6. Only one person had elementary education, 8 people had vocational education, 34 people had secondary education, and 28 people had higher education. Due to the large number of patients with secondary and higher education, the results of these groups were compared on the basis of the analysis of variance in the Levene's test. The statistical significance of the test exceeded 0.05 (0.912). The Analysis of Variance (ANOVA) - 0.627. Thus, there is no reason to reject the hypothesis of the lack of differences in the AIS test results between a group of people with secondary education and a group of people with higher education.

Table 7 presents the degree of acceptance of illness, depending on patients' professional status. The results obtained by working patients and pensioners allowed a statistical analysis to be performed. The statistical significance obtained in the test of homogeneity of variance did not exceed 0.05, amounting to 0.05, which means that
Table 3. Degree of acceptance of the disease and the diagnosis of metastases

\begin{tabular}{lccc|}
$\begin{array}{l}\text { Have your cancer } \\
\text { metastasized? }\end{array}$ & $\boldsymbol{N}$ & Average & Standard deviation \\
Yes & 32 & 24.25 & 8.666 \\
No & 38 & 30.71 & 7.059 \\
I don't know & 1 & 14.00 &. \\
In total & 71 & 27.56 & 8.522 \\
\hline
\end{tabular}

Table 4. Degree of acceptance of the disease and gender

\begin{tabular}{|lccc|} 
Gender & $\boldsymbol{N}$ & Average & Standard deviation \\
\hline Female & 29 & 29.59 & 7.684 \\
Male & 42 & 26.17 & 8.876 \\
\hline In total & 71 & 27.56 & 8.522 \\
\hline
\end{tabular}

Table 5. Degree of acceptance of the disease and age

$\begin{array}{llcc}\text { Age } & \boldsymbol{N} & \text { Average } & \text { Standard deviation } \\ \text { Aged up to 55 years } & 23 & 28.00 & 7.49 \\ \text { Aged 55-65 } & 27 & 27.74 & 8.88 \\ \text { Aged 65 and over } & 21 & 26.86 & 9.44 \\ \text { In total } & 71 & 27.56 & 8.52\end{array}$

Table 6. Degree of acceptance of the disease and the level of education

\begin{tabular}{|lccc|}
\hline Level of education & $\boldsymbol{N}$ & Average & Standard deviation \\
\hline Elementary education & 1 & 37.00 &. \\
\hline Vocational education & 8 & 26.38 & 8.717 \\
\hline Secondary education & 34 & 26.94 & 8.574 \\
\hline Higher education & 28 & 28.32 & 8.598 \\
\hline In total & 71 & 27.56 & 8.522 \\
\hline
\end{tabular}

Table 7. Degree of acceptance of the disease and professional status

\begin{tabular}{|lccc|}
\hline Professional status & $\boldsymbol{N}$ & Average & Standard deviation \\
\hline Working person & 30 & 28.90 & 7.102 \\
Student & 2 & 29.50 & 13.435 \\
\hline Pensioner & 35 & 26.17 & 9.259 \\
Homemaker & 2 & 30.50 & 6.364 \\
Unemployed & 1 & 40.00 &. \\
\hline In total & 71 & 27.56 & 8.522 \\
\hline
\end{tabular}

the homogeneity of variance assumption must be rejected. The use of the analysis of variance to compare the two groups is unauthorized in this case. The Mann-Whitney $U$ test was carried out. The statistical significance of the test exceeded the value of 0.05 (asymptotic/bilateral significance amounted to 0.206). This indicates that there was no basis for rejecting the hypothesis that there was no difference between the two studied groups of working people vs. pensioners.

Table 8 presents the degree of acceptance of illness in patients depending on the size of the city where they permanently live. The inhabitants of cities with a population 
Table 8. Degree of acceptance of the disease and the place of residence

\begin{tabular}{|c|c|c|c|}
\hline Place of residence & $N$ & Average & $\begin{array}{l}\text { Standard } \\
\text { deviation }\end{array}$ \\
\hline Countryside & 5 & 25.60 & 7.127 \\
\hline $\begin{array}{l}\text { Cities up to } 20,000 \\
\text { inhabitants }\end{array}$ & 9 & 26.56 & 6.227 \\
\hline $\begin{array}{l}\text { Cities up to } 50,000 \\
\text { inhabitants }\end{array}$ & 9 & 23.44 & 8.575 \\
\hline $\begin{array}{l}\text { Cities up to } 100,000 \\
\text { inhabitants }\end{array}$ & 10 & 28.30 & 8.499 \\
\hline $\begin{array}{l}\text { Cities up to } 500,000 \\
\text { inhabitants }\end{array}$ & 1 & 22.00 & . \\
\hline $\begin{array}{l}\text { Cities of more than } 500,000 \\
\text { inhabitants }\end{array}$ & 37 & 29.03 & 9.182 \\
\hline In total & 71 & 27.56 & 8.522 \\
\hline
\end{tabular}

Table 9. Degree of acceptance of the disease and the average monthly income per family member in the household

\begin{tabular}{lccc}
$\begin{array}{l}\text { Average monthly income } \\
\text { per family member in the } \\
\text { household. }\end{array}$ & $\boldsymbol{N}$ & Average & $\begin{array}{l}\text { Standard } \\
\text { deviation }\end{array}$ \\
$\begin{array}{l}\text { Less than 500 PLN } \\
\text { Between 501 and 1000 PLN }\end{array}$ & 4 & 30.75 & 7.365 \\
\hline Between 1,001 and 1,500 PLN & 18 & 25.50 & 8.295 \\
Between 1,501 and 2,000 PLN & 12 & 30.83 & 8.333 \\
2,000 PLN and over & 17 & 29.00 & 7.715 \\
\hline No answer given & 4 & 26.00 & 9.631 \\
In total & 71 & 27.56 & 8.522 \\
& & &
\end{tabular}

Table 10. Degree of acceptance and the marital status

$\begin{array}{lccc}\text { Marital status } & \text { Average } & \boldsymbol{N} & \text { Standard deviation } \\ \text { Single } & 25.75 & 4 & 9.032 \\ \text { Married } & 27.37 & 54 & 8.736 \\ \text { Widowed } & 28.56 & 9 & 9.248 \\ \text { Divorced } & 29.33 & 3 & 5.686 \\ \text { No data available } & 31.00 & 1 & . \\ \text { In total } & 27.56 & 71 & 8.522\end{array}$

greater than 500,000 were characterized by the highest degree of acceptance of the state of health (on average 29.03). The inhabitants of cities with a population smaller than 500,000 had the lowest degree of acceptance of the illness. However, due to the very small size of this group of respondents (1 person), the result cannot be taken as a regular result. Among the rural population, the average acceptance of the illness amounted to 25.6 points. Since the groups were not equal in number, the statistical analysis was not performed.

Table 9 presents the degree of acceptance of illness according to the average net monthly income per family member in the household. Since the groups were not equal in number, the statistical analysis was not performed. Patients with income between 1,001 PLN and 1,500 PLN, were the largest group of respondents. In this group, the average degree of acceptance of the illness amounted to 25.83 points. The lowest degree of acceptance of illness was observed in the group with average incomes ranging from 501 PLN to 1,000 PLN.

Table 10 presents the degree of acceptance of cancer among patients depending on their marital status. Married people represented the largest group of patients (54 individuals). In this group, the average degree of acceptance of illness amounted to 27.37 points. The second largest group were widowers/widows and their average degree of acceptance of illness reached 28.56. Patients who declared themselves as single represented a group of four people with an average degree of acceptance of illness at the level of 25.75. Since the groups were not equal in number, the statistical analysis was not performed.

\section{Discussion}

For the group of patients included in the study, the arithmetic mean amounted to 27.56 points, and the standard deviation amounted to 8.522 which is a relatively high level of acceptance of cancer. For example, the arithmetic mean for patients with chronic pain, amounted to 18.46 (the standard deviation amounted to 7.05), while for women with breast cancer and cervical cancer the arithmetic mean amounted to 28.13 (the standard deviation amounted to 7.6) [4]. Felton et al., who analyzed patients with chronic illnesses, obtained a general higher score of acceptance of illness in comparison with his own research. The mean value of AIS test was 28.08 [11]. When we compare the outcomes with the results of other studies applying the acceptance of illness scale (AIS) in patients diagnosed with cancer, our results are higher than in the case of leukaemia patients. Wiraszka and Lelonek indicate that the mean score in the latter group of patients was 23.27 [12].

The main socio-economic factor, which influenced the AIS test results was whether metastases were diagnosed or not. Patients not diagnosed with metastases had a higher degree of acceptance of the illness than patients diagnosed with metastases. Other studies confirmed this correlation [11, 13, 14].

In our own research, there were no differences between patients in groups where the time that elapsed from the first diagnosis of cancer varied. However, other studies have confirmed the correlation between the acceptance of the illness and the time of its duration. Higher degree of acceptance of illness was observed in patients who had undergone mastectomy less than 2 years before [13]. In this study, no significant difference between the acceptance of illness and the age of the respondents was proven. In our research, there were no statistical differences between patients of different age. However, M. Ogińska-Bulik's analyses show that the degree of illness acceptance correlates with women's age. Post-mastectomy patients below the age of 55 show the average acceptance of illness at 31.27, whereas in the case of older patients the result proves evidently lower (25.93) [15].

The degree of acceptance did not dependent on the place of residence and the level of education [13]. Furthermore, the level of education and professional status did 
not impact the AIS test results in our research. Rolka also points that the degree of acceptance of cancer does not depend on the level of education [14]. However, other studies have confirmed the correlation between AIS test results and the level of education. Similar conclusions were drawn by Basinska and Andruszkiewicz when analysing patients with Graves' illness and Hashimoto's thyroiditis [16].

The impact of external factors, including socio-economic, on the quality of life of patients with chronic illnesses is an important research area. For example, a study of the effects of chemotherapy on the quality of life in patients with metastatic ovarian cancer shows that during the treatment the quality of life of patients is reduced. The physical symptoms associated with chemotherapy influence the way these patients perceive the illness and that, in turn, influences their quality of life. All types of therapeutic measures, aimed at reducing side effects of the treatment, significantly improve the quality of life. The correlation between age and the quality of life in patients with ovarian cancer was also noted. In women aged 50 and over, it is mainly the physical symptoms associated with the illness and treatment that deteriorate their quality of life. However, younger patients experience higher levels of anxiety and the improvement of their quality of life should be done through psychological care. Providing honest information concerning the illness, as well as, possible methods of treatment is of considerable importance. Well-informed patients rate their quality of life significantly higher as opposed to the less-informed [17].

In another study on female patients diagnosed with cervical cancer, who had had the Wertheim-Meigs surgery at least 10 years earlier, the relationship between the assessment of the working and social environment, health, satisfaction with physical appearance versus the assessment of quality of life was established [18]. This confirms the complexity and multidimensionality of the quality of life issues and potential difficulties that a precise assessment of this category may pose.

A different study conducted on a group of 44 individuals with multiple sclerosis, has demonstrated that the Acceptance of Illness Scale (AIS) is a good indicator of the quality of life determined by the illness, identified with satisfaction with life, and assessment of the current state of health [19].

In conclusion:

1. The average degree of acceptance of illness in the study group was 27.56 points, which is a relatively high level of acceptance of cancer.

2. The main socio-economic factor which impacts the AIS test results is whether metastases were diagnosed or not.

3. There are no differences in results between patients in groups where the time that elapsed from the first diagnosis of cancer varied. There are no statistical differences between female and male patients, and between patients of different age. Moreover, the level of education and professional status does not make any differences in the AIS test results.

The authors declare no conflict of interest.

\section{References}

1. Stolarska M. Problems associated with the study of the quality of life of cancer patients. Available at: http://www.psychologia.edu. pl/czytelnia/50-artykuly/212-problemy-zwiazane-z-badaniem-jako sci-zycia-pacjentow-onkologicznych.html [Access: date 15.05.2014].

2. Unger C, Weis J. Oncology: Unconventional methods and supportive ways of therapy - therapeutic strategies. Wydawnictwo MedPharm Polska, Wrocław 2008; 56 [in Polish].

3. Dorfmüller M., Dietzfelbinger H. Psychooncology: diagnosis - treatment methods. Elsevier Urban \& Partner, Wrocław 2011; 60 [in Polish].

4. Juczyński Z. Measurement tools in the promotion and psychology of health. Pracownia Testów Psychologicznych, Warsaw 2009; 164 [in Polish].

5. De Walden-Gałuszko K. Psychooncology. Komitet Redakcyjno-Wydawniczy Polskiego Towarzystwa Psychiatrycznego, Kraków 2000; 5 [in Polish].

6. Synowiec-Piłat M. Health promotion and preventive oncology in the activities of non-governmental organizations]. 98-100 [in Polish].

7. RAPORT Financing health care in Poland, Green Paper II, the third version. Warsaw 2008. [in Polish].

8. Governmental Resolution on the National Programme for Combating Cancer. Available at: http://www.rynekzdrowia.pl/ Serwis-Onkologia/Rzadowa-uchwala-w-sprawie-NarodowegoProgramu-Zwalczania-Chorob-Nowotworowych,129715,1013. html [in Polish].

9. Oncological care systems in selected countries, April 2014, Report prepared by EY commissioned by Fundacja Onkologia 2025 [in Polish].

10. Preventive and Environmental Medicine], Jethon Z, Grzybowski A (eds.). Wydawnictwo Lekarskie PZWL, Warsaw 2000; 138-142 [in Polish].

11. Felton BJ, Revenson TA, Hinrichsen GA. Stress and coping in the explanation of psychological adjustment among chronically ill adults, Social Science and Medicine 1984; 18: 889-898.

12. Wiraszka G, Lelonek B. Funkcjonowanie chorego z białaczką a akceptacja choroby nowotworowej. Studia Medyczne 2008; 10: 21-26.

13. Pawlik M, Karczmarek-Borowska B. Acceptance of cancer in women after mastectomy. Przegląd Medyczny Uniwersytetu Rzeszowskiego i Narodowego Instytutu Leków w Warszawie, Rzeszów 2013; 203-211 [in Polish].

14. Rolka H, Krajewska-Kułak E, Kułak W, et al. Akceptacja choroby i strategie radzenia sobie z bólem jako istotne komponenty oceny jakości życia zależnej od stanu zdrowia u chorych z migreną. Doniesienie wstępne. Problemy Pielęgniarstwa 2009; 17: 178-183.

15. Ogińska-Bulik M. Rola prężności psychicznej w przystosowaniu się kobiet do choroby nowotworowej. Psychoonkologia 2011; 1: 16-24.

16. Basinska MB, Andruszkiewicz A. Health Locus of Control in Patients with Graves-Basedow Disease and Hashimoto Disease and Their Acceptance of Illness. Int J Endocrinol Metab 2012; 10: 537-542.

17. Głuszak JK, Wieloszewska K. Effectiveness of chemotherapy in improving the quality of life in patients with metastatic ovarian cancer. Polska Medycyna Paliatywna 2006; 5: 126-130.

18. Bidzan M, Rudnik A, Peplińska A. Correlates between different areas of life of women after Wertheim-Meigs cervical cancer surgery in relation to the quality of life. Psychoonkologia 2013, 2: 62-70.

19. Juczyński Z. Measurement tools in the promotion and psychology of health. Pracownia Testów Psychologicznych, Warsaw 2009; 163 [in Polish].

\section{Address for correspondence}

\section{Aleksandra I. Czerw}

Department of Public Health,

Medical University of Warsaw

Zwirki Wigury

08-456 Warsaw, Poland

e-mail: aleksandra.czerw@wum.edu.pl

Submitted: 23.09 .2014

Accepted: $\quad 27.05 .2015$ 